\title{
The Developing on Awareness of Water Resources Management of Grade 6 Students in Namphong Sub-Basin
}

\author{
Lumyai Seehamat ${ }^{1}$, Unchalee Sanrattana ${ }^{1} \&$ Angkana Tungkasamit ${ }^{1}$ \\ ${ }^{1}$ Department of Curriculum and Instruction, Khon Kaen University, Thailand \\ Correspondence: Unchalee Sanrattana, 123 Moo 16 Department of Curriculum and Instruction, Faculty of \\ Education, Khon Kaen University, Thailand. Tel: 66-814-061-462. E-mail: unesar@kku.ac.th
}

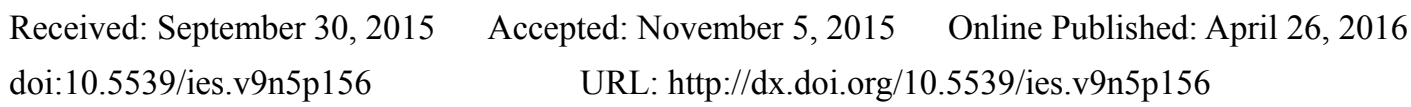

\begin{abstract}
Awareness of water resources management is expression behavior as receive, response, valuing, and organization. Water resources is an important for everyone in the world and the recently water resources are be risky as lack of water, waste water, and blooding. The development on awareness of water resources management for grade 6 students is very important to solve immediately. The objectives of this research were to 1) compare grade 6 students' awareness and comprehension of water resources management after developing 2) compare grade 6 student's awareness and comprehension of water resources management after developing between irrigated area and non- irrigated area. The research was quasi-experimental design. The samples of control group were 31 students and 61 students were experimental group. Research instruments were the curriculum for developing awareness of water resources management, water resources management comprehension test, and assessment form for awareness of water resources management. Data analyzed were used descriptive statics for mean, standard deviation, and independent t-test used for comparing mean scores of pretest and posttest. The research found that the pretest and posttest of students' awareness of water resources management and comprehension were significantly different at .05 levels. The compare mean between students' awareness and comprehension in irrigated zone and non-irrigated zone were not significantly different at .05 levels.
\end{abstract}

Keywords: awareness, developing awareness, Namphong sub-basin

\section{Introduction}

According to the National Educational Act 1999, and the Amended Act 2002, stated in Section 27 paragraph 1 that Board of Education define the core curriculum for basic education to be good Thai citizens and for the good careers, paragraph 2 that basic education schools has been prepared strand of school curriculum correlated to paragraph 1 about problems in our communities and society local wisdom, desirable characteristics for a good member of the family community, society and nation. The important point of National Educational Act was decentralization to basic education schools that prepared strand and substance of school curriculum related to local requirements. And the most important to development our citizen is decentralization of policy that each school selected the content of school curriculum for relevance to local problem and according to Office for National Education Standards and Quality Assessment stated in standard 3 and standard 7 that students have a conscience for the sake of public interest in conservation and environmental development and students appreciate the wisdom, pride in Thailand, artistic and beauty cultural of Thailand (The Office of National Educational Commission, 2002; the Office of Secretariat in Educational Council, 2010).

Nampong sub-basin covers an area of five provinces in Northeast of Thailand such as Loei, Udonthani, Khonkaen, Nongbualumphu, and Mahasarakham provinces. Namphong sub-basin is an area of about 2,386 square kilometers $(1,491,250$ acres) representing 4.82 percent of the watershed in Thailand. Namphong sub-basin is a large reservoir including the lake reservoir as Ubolratana dam and the storage capacity of 2,230 million cubic meters. Namphong sub-basin divide in 2 areas are Namphong sub-basin in upper and Namphong sub-basin in lower. Namphong sub-basin upper area most of the area is upland terrain is experiencing a shortage of water and Namphong sub-basin lower area of Ubolratana dam is the most of the plains. In 2003 Namphong sub-basin lower area have 510,381 population with an average density of 213.91 people per square kilometer within the next 30 years will have population about 769,475 . The average annual rate of increase of the population accounted for 1.34 percent. It has an average density of 322.50 people per square kilometer. 
Namphong sub-basin lower area 39,235 acres divide to for agricultural 15,694 acres and using the water 398.79 Million cubic meters per year and within the year 2022 there will need to 421.82 million cubic meters of water per year. The water for industrial in 200713.16 million cubic meters of water per year and within the year 2022 there will need to 47.47 million cubic meters of water per year. Lastly the water for household consumption 23.49 million cubic meters of water per year and within year 2022 there will need 30.67 million cubic meters of water per year. In 2006 the total of water plus agricultural, industrial, household consumption were 435.44 million cubic meters of water per year and within year 2022 there will need the total of water are 499.96 million cubic meters of water per year. The water for important past maintains ecological balance equal 37.70 million cubic meters of water per year. In 2006 the investment on water are 2101.04 million baht per year that is the high cost and will be higher in the future because of the demand for water and the increase in population has increased rapidly every year. (Department of irrigation, 2006)

Namphong sub-basin is growth of the industry so fast then the population of the Namphong sub-basin is increase dramatically. The demand for water is increasing every year, such have a problem as 1) Shortage of water for agriculture and consumption in summer. 2) The problems of flooding on the living space, agricultural areas during the rainy season 3) Problems of water resources, soil conservation, water resources, forests and environment are invading, occupying an area of water resources and green river. All the problem effect on shallow water and ridge to river 4) the discharge of sewage from communities and industry to the Namphong sub-basin such as communities, hospital, hotel, market and slaughterhouse all the waste water from those places are make available water sources and the area was contaminated. 5) The water resources management inefficiency caused water shortages and pollution in flood water and the problem between the users and the staff within sectors. The establishment and strengthening of water users, including building awareness for youth and paradigm of water users in all sectors of awareness and practice of management and exploitation from the water with good governance in the management of water resources (Buarapa, 2004; Department of Water Resources, 2006).

The analysis of the real causes of the disaster flooded area along the Namphong sub-basin, water shortages, and waste water in the Namphong sub-basin mentioned above occur unless caused by climate change, It also caused by human action, who ignorance and lack of awareness of the quantity of water resources are limited and the lack of social responsibility. The solution also needed to strengthen the knowledge, skills and experience they need to develop the minds of all water use sectors, by raising awareness of water users will appreciate, the importance of water to the environment. When the user put it, no matter where you are when you realize the importance of water resources would be responsible for their actions, the benefit of society as a whole rather than own these feelings to control behavior. The people are more environmentally conscious (Yodmanee, 1989).

Clark and Squire (1998) found that Awareness of the human and vertebrates caused by Hippocampus and Parahippocampus of the brain. This brain area is closely linked to the knowledge that is abstract. Bloom, Krathwhol, and Masia (1964) classified the human learning into three areas: cognitive domain, affective domain and psychomotor domain. Sensation coming into our human learning occurs from the affective domain and sent me to the cognitive and psychomotor domain which from the behavior and show off, to see that knowledge in the mental is particularly important because it is the recipient of information into the process. Then came the beginning of a learning process, until the show was a learned behavior to expect that the process of awareness that study by Depraz et al. (2003). The gesture becomes aware. They found that awareness has 3 stages 1) A phase of suspension for a period of consideration of the character, this is the first condition that is the basis for the interest in the subject to experience and to demonstrate the skepticism inherent or not from. In short, the attitude that the formation of the habit of thinking, it stems from personal appearance in the world of reality, a sense of personal style and habits of thinking that is part of the complex web called ecology of though, which is located in the unit's memory and selfish will come from the collection of the environment around the person, in this suspicion, the person will be a movement of thought and extend to the interpretation of what is real 2) Redirecting thoughts as of the attention from what is seen outside and then sent to the interior, which is a form of thought temporarily by the Spirit, we are waiting for the event to appear in the form of content, layout, signal. Depraz (1999) said that "as a temporary phase of which is a result of the new requirements." The understanding of this individual would have predicted in advance what to do and when to stop is related to attitude always. 3) Letting go of assumptions and memories as a stable and a clear aim by not clinging to feel bound in a range of modifications that have been and can be returned to emerging 1st stage.

The process of awareness of human on water resources, UNESCO has recognized the importance of the seminar on environmental education organization UNESCO, has set goals and objectives into four namely, awareness, knowledge, attitudes, skills and participate in (UNESCO, 1978) subsequently, the management of public schools 
in the state of Florida has taken environmental education curriculum with an emphasis on three main aims attitudes, knowledge and awareness (Lavega, 2004; Schiffries \& Brewster, 2004) has summarized the symposium on the topic of water for a sustainable future and secure, with urgent policy haves nine courses must carry and is one of the nine key areas and improve education. Outreach in sustainable water management. It can be seen that education is necessary to highlight the awareness that individual behavior is expressed. With the perception that full understanding of internal and/or external environment that expresses remember, recognize, or understand.

The importance is the value of the thing or the sort of event that was born from the idea to the brain, which consists of five stages: 1) knowledge means that students from attending class activities. Teaching about the management of water resources, 2) recognition means the level of knowledge seemed obvious that a focus on the management of water resources, is expressed by the participants' hearing, the collector admittedly, as well as differentiate three response means that the level of knowledge seemed clear that satisfaction with the management of water resources. Is expressed by the search, collection, agrees to agree to volunteer as well as the support 4) the value represents the level of knowledge seemed obvious to see the value or importance of water resource management, there. The express by joining the campaign, demonstrations, lectures, knowledge, comments and support to help inspire others, and 5) the value system. Means the level of knowledge seemed obvious that a summary of the value of water resources management on a law or principle. A proposal in practice because they believe it is a good thing, is expressed by the arrangements, the comparison as well as the principles to practice.

Students in the primary level are major developments include Havighurst (1952) to learn the skills necessary to play the game and the sport has created attitudes toward themselves as creatures that are growing, learning to adapt to their peers. Learn the role of a male and female, according to the social set. Develop ideas about what is needed for survival on a daily basis. Development of consciousness, ethics and values, starting with the requirement of independence, is one's own, develop habits, social and institutional development of the above are important to being a good citizen in society. And age appropriate for the development of public awareness. Awareness of individuals who happen to both internal and/or external environment, expresses the experience is present, the awareness, understand, feel, desire, or intention, which is to lead to the expression of behavior is the first step. The affective domain that recalled knew or had knowledge of the world around them and has an idea to do something on the problem for the survival of society and the environment (Krathwohl, 1985; Karnden \& Wannapok, 2006; Cardaciotto, 2005; Power, 2011; Freeman, 2000; Varela et al., 1993).

Teaching activities to enhance awareness we have divided into 4 units. The first unit is knowledge of water resources, subdivided into 1.1 the properties of water and water cycle 1.2 the relationship between soil, water, forests, plants, animals, and human resources. The unit 2 is local water subdivided into 2.1 second local water problems with water shortages, droughts, floods, wastewater and 2.2 monitoring water quality and water quality monitoring. The unit 3 water use efficiency 3.1 appreciate the value of water use efficiency, water saving, reused therapy and then reused again to build mental Bureau. And the paradigm shift in water use efficiency. 3.2 Water for communities. The last unit 4 is Thailand wisdom of water 4.1 Literary traditions on the water 4.2 Water festival.

Thus enhancing awareness on the management of water resources for youth that will need to go through the process of education is a cornerstone in the creation of prosperity and solutions in developing countries because of the relationship directly to the development of human resources in the country to recognize individuals who think, well done, as well as solutions using available resources to the maximum.

\subsection{Conceptual Framework}

Enhancing the awareness on water resources management, grade 6 students in Namphong sub-basin, researchers have started to study variable or component related to water resources management, namely, the definition of water resources. The definition of water resources management, asset management concept in hard water, the problems regarding the management of water resources, context and condition of Namphong sub-basin. Then analyze the process of awareness which has five stages, namely knowledge, awareness, response, providing value and value systems. Knowledge is what the students of the teaching activity on water resources management is perceived as a diverse spectrum of knowledge seemed obvious that a focus on water resource management. Is expressed by the participants have been admitted, as well as a collection of distinction. The response was that it seemed clear that the level of satisfaction regarding the management of water resources. Is expressed by the search, collection, agrees to agree to volunteer as well as the support. The value is the level of knowledge seemed obvious to see the value or importance of water resources management is expressed by 
joining the campaign, demonstrations, lectures, knowledge, comments, as well. The value system is the level of knowledge manifested a clear conclusion about the value of the management of water resources as a rule or principle to a proposal in practice because they believe it is a good thing, is expressed by arrangement, comparison, as well as the principles to practice with awareness of water resource management. The elements of curriculum as instruction, material, measurement and evaluation are important. The sort of content that is consistent with the context of local activities, teaching focused on practical and challenging, materials and resources, are appropriate to the learner and the context of local, supporting, learning and assessment the awareness on water resources management.

\section{Research Objectives}

1) To compare grade 6 students' awareness and comprehension of water resources management after developing.

2) To compare grade 6 student's awareness and comprehension of water resources management after developing between irrigated area and non-irrigated area.

\section{Research Hypothesis}

1) Student comprehension and the awareness on water resources management were higher than before the experiment.

2) Students in the area of irrigation with students in non-irrigated areas have the knowledge and awareness on different water resources management.

\section{Research Methodology}

\subsection{Research Design}

This research design was a quasi-experimental. The design was divided to control group pretest posttest design (Cohen \& Manion, 1980).

\subsection{Population}

The population of this investigated were 2,605 grade 6 students in Namphong sub-basin of Khon Kaen primary education area zone 4 in Northeastern of Thailand in 2014.

\subsection{Sample}

The sample of this investigated were grade 6 students in Namphong Sub-basin were follow; control group 31 students and experimental group 61 students was by Simple sampling.

\section{4 Variables}

\subsubsection{Independent Variables}

1) A Curriculum for Developing Awareness of Water Resources Management (WRM) of grade 6 students in Namphong Sub-basin, Thailand.

2) Area of school such as irrigated zone and non- irrigated in Khon Kaen primary education area zone 4 in Northeastern of Thailand.

\subsubsection{Dependent Variables}

1) The scores of comprehension of water resources management.

2) The scores of awareness of water resources management.

\section{Research Instruments and Procedure}

\subsection{Research Instruments}

\subsubsection{The Instruments Used for Developing Awareness of Water Resources Management}

1) The lesson plan based on the Curriculum for developing awareness of water resources management for grade 6 students in Namphong sub-basin created by investigator 2) learning units 3) the Teachers' teaching behavior observation form.

\subsubsection{The Instruments Used for Comparing the Awareness of Water Resources Management}

1) Water resources management comprehension test 2) assessment form for awareness of water resources management.

\subsection{Procedure}

1) Written the letter from the faculty of education in Khon Kaen university to Ban Sam Sung school, Khon Kaen 
Province that has not been set in non-irrigate area and Prabattharue school in irrigate school were experimental group. The collecting data of curriculum implementation and follow-up by observed the activity in classrooms as a behavior of teachers and behavior of students, classroom climate, interesting the activities of students.

2) Written the letter from the faculty of education in Khon Kaen university to Nongwaengkoopasart school, Khon Kaen Province that has not been set in non-irrigate area and Koksoongkudnumsai school in irrigate area were control group. The collecting data of control group by using the comprehension and awareness of water resources management in pre-test and posttest examination.

3) The Schedule of collected data 2nd August 2014 to collected pretest examination of control and experimental group. During the activities of curriculum ongoing the investigator were observed in the classroom with control and experimental group. The posttest examination on 27th September, 2014.

4) Summary developing of awareness on water resources management of sample group. Then write the report of research.

\subsection{Data Analysis}

1) Statistical methods used in the research. The researchers used descriptive statistics include mean and standard deviation.

2) Referential statistical methods by used independent t-test to compare the difference of points of measurement of comprehension and awareness of water resources management for grade 6 students between the before and the after.

\section{Results}

The pretest result of comprehension test and awareness of water resources management test before the developing awareness of water resources management are follow:

Table 1. Comparing average scores between the experimental and control groups before treatment

\begin{tabular}{lllllll}
\hline \multirow{2}{*}{ Scores } & Sample & $\mathrm{N}$ & $\bar{x}$ & S.D. & t-test & \multirow{2}{*}{ Sig. } \\
& & & & & & \\
\hline \multirow{2}{*}{ Comprehension scores } & Control group & 31 & 17.90 & 2.72 & \multirow{2}{*}{0.081} & \multirow{2}{*}{.935} \\
& Experiment group & 61 & 17.95 & 2.62 & & \\
\multirow{2}{*}{ Awareness scores } & Control group & 31 & 88.29 & 7.12 & & \multirow{2}{*}{.630} \\
& Experiment group & 61 & 83.09 & 7.72 & & \\
\hline
\end{tabular}

$\mathrm{t}=0.081 ; \mathrm{p}<. \overline{05}$.

Table 1 shows a comparison of the average comprehension scores between the experimental group and control group showed that the experimental group's average score was higher than the control group. The mean difference $(d=-0.047)$, where no such difference was statistically significant level. 05 (p-value $=0.935)$ and standard deviation of the awareness between the experimental and control groups before. It was found that the mean score of the control group were higher. The average difference $(d=5.19)$, where no such difference was statistically significant level. $05(\mathrm{p}$-value $=0.630)$.

Table 2. Compares the average of comprehension and awareness of water resources management between irrigated area and non-irrigated area before the treatment

\begin{tabular}{lcccccc}
\hline Scores & Sample & $\mathrm{N}$ & $\bar{x}$ & S.D. & t-test & Sig. \\
\hline \multirow{2}{*}{ Comprehension scores } & Non-irrigate area & 42 & 17.54 & 2.71 & \multirow{2}{*}{1.293} & \multirow{2}{*}{.199} \\
& Irrigate area & 50 & 18.26 & 2.56 & & \\
\hline \multirow{2}{*}{ Awareness scores } & Non-irrigate area & 42 & 84.11 & 8.12 & \multirow{2}{*}{.811} & \multirow{2}{*}{.419} \\
& Irrigate area & 50 & 85.46 & 7.70 & & \\
\hline
\end{tabular}

$\mathrm{p}<.05$. 
Table 2 shows a comparison of the average comprehension score between the groups is irrigated and non-irrigated before the treatment found that the mean score of the group that is irrigated area higher than non-irrigation area. The mean difference $(\mathrm{d}=0.70)$, where the difference has no statistical significance level. 05 (p-value $=0.199$ ) and standard deviation of the awareness among the group that is irrigated and non-irrigated before the trial found that the mean score of the group that is irrigated higher outside irrigation. The average difference $(\mathrm{d}=1.34)$, where no such difference was statistically significant level. 05 ( $\mathrm{p}$-value $=0.419)$.

The posttest result of comprehension test and awareness of water resources management test before the developing awareness of water resources management are follow:

Table 3. Compares the average of the comprehension and the awareness of water resource management between the experimental group and control groups after the treatment

\begin{tabular}{|c|c|c|c|c|c|c|}
\hline Scores & Sample & $\mathrm{N}$ & $\bar{x}$ & S.D. & t-test & Sig. \\
\hline \multirow{2}{*}{ Comprehension scores } & Control group & 31 & 17.90 & 3.14 & \multirow{2}{*}{4.082} & \multirow{2}{*}{$.000^{*}$} \\
\hline & Experiment group & 61 & 20.60 & 2.92 & & \\
\hline \multirow{2}{*}{ Awareness scores } & Control group & 31 & 85.22 & 8.05 & \multirow{2}{*}{3.115} & \multirow{2}{*}{$.002 *$} \\
\hline & Experiment group & 61 & 90.19 & 6.78 & & \\
\hline
\end{tabular}

$\mathrm{p}<.05$.

Table 3 shows a comparison of the average comprehension scores between the experimental group and control groups after the treatment showed that the mean score of the experimental group higher than the control group. The mean difference $(\mathrm{d}=2.70)$, which is the difference of such a statistically significant level. 05 ( $\mathrm{p}$-value $=$ 0.000) and standard deviation of the awareness between the treatment and control groups after. It was found that the mean score of the experimental group than the control group. The average difference $(\mathrm{d}=4.97)$ which distinguish the level of statistical significance. $05(\mathrm{p}$-value $=0.002)$.

Table 4. Compares the average of comprehension and awareness of water resources management between irrigated and non-irrigated area after treatment

\begin{tabular}{lcccccc}
\hline Scores & Sample & $\mathrm{N}$ & $\bar{x}$ & S.D. & t-test & Sig.(2 tailed) \\
\hline \multirow{2}{*}{ Comprehension scores } & Non-irrigate area & 42 & 19.67 & 3.36 & \multirow{2}{*}{ (c78 } & .938 \\
& Irrigate area & 50 & 19.72 & 3.18 & & \\
\hline \multirow{2}{*}{ Awareness scores } & Non-irrigate area & 42 & 87.04 & 8.98 & \multirow{2}{*}{1.730} & .087 \\
& Irrigate area & 50 & 89.76 & 5.96 & & \\
\hline
\end{tabular}

$\mathrm{p}<.05$.

Table 4 shows a comparison of the average comprehension score between the irrigated area and non-irrigated area posttest mean scores of the group is irrigate area higher than non-irrigate area. The mean difference $(\mathrm{d}=$ 0.053), where the difference has no statistical significance level. 05 ( $\mathrm{p}$-value $=0.938$ ) and standard deviation of the awareness among the group that is irrigated and. Non-irrigated after the treatment found that the mean score of the group that is irrigate area higher than non-irrigate area. The average difference $(d=2.712)$, which was no such difference was statistically significant level. $05(\mathrm{p}$-value $=0.087)$. 
Table 5. Compares the average of comprehension and awareness of water resources management between experimental groups within irrigate area and non-irrigate area after treatment

\begin{tabular}{lcccccc}
\hline Scores & Sample & $\mathrm{N}$ & $\bar{x}$ & S.D. & t-test & Sig.(2 tailed) \\
\hline \multirow{2}{*}{ Comprehension scores } & Non-irrigate area & 26 & 20.92 & 2.84 & \multirow{2}{*}{.725} & \multirow{2}{*}{.674} \\
\cline { 2 - 6 } & Irrigate area & 35 & 20.37 & 3.01 & & \\
\hline \multirow{2}{*}{ Awareness scores } & Non-irrigate area & 26 & 89.30 & 8.80 & \multirow{2}{*}{0.880} & \multirow{2}{*}{.382} \\
& Irrigate area & 35 & 90.85 & 4.81 & & \\
\hline
\end{tabular}

$\mathrm{t}=0.725 ; \mathrm{p}<.05$

Table 5 shows a comparison of the average comprehension score between the groups in the irrigate area and non-irrigate areas after treatment showed that the average of comprehension score of non-irrigate higher than in irrigate area. The mean difference $(d=0.55)$, where the difference has no statistical significance level .05 $(p$-value $=0.674)$ and standard deviation of the awareness among treatments in the area. Irrigate area and nonirrigate areas after treatment showed that the average of the awareness of the group is irrigate area higher than non-irrigate area. The average difference $(\mathrm{d}=1.54)$, where no such difference was statistically significant level .05 (p-value $=0.382)$.

\subsection{The Results of Student's Awareness}

The analysis of the works of students in the learning activities, the instructors develop awareness of water resources management. The research presents detailed respectively as below.

1) Recognition that the students in his school and home port, which is a frustration in the experimental group participated in developing awareness on water resources management. Students can use the senses to recognize by sight, hearing, smell and taste, and contact with skin. Based on previous experience based learning experience, motivation and emotional state of mind in the present form of provocation. The activities allow students to use sensory awareness in all activities. For example, students have expressed such a wonderful event and a fountain of water in a bottle. Students get to know the relationship of water and pressure, and also linked to daily life is to bring this principle to water with a bucket of water and a bucket of water on the building. Students are recognizing the value of water like electricity from hydro power knowledge about water and water resources.

2) The response from the teaching activities of the course is to develop awareness on water resources management of the six-year study found that the response of the students. The expression of emotion and knowledge show by the retaliation activities that teachers can offer students a great cause. Studies have knowledge search Gathering knowledge judging by the mood in follow agreed to volunteer as well as the support. Students have responded to the activities to develop awareness of water resource management, with a note in the group.

3) Their value to the student participants to develop awareness on water resources management division students to demonstrate their value to. The management of water resources is a substance or object as felt needs, beliefs, interests, abilities and behavior to be consistent look. The important are clear and sentimental to love and cherish the anxiety and concern.

Student Work from the students to demonstrate the value of water in the economic, social and cultural environment. Students also mentioned that water is vital to human, animals, plants producing electricity from hydropower.

4) The value system of student work that students have expressed the feelings and emotions that are expressed as naturally as possible on the situation at the moment is that students have the virtue of those who use the water will be. You will save the unity plan to provide clean water to use.

\section{Discussions}

The development of awareness on water resources management found that students who pass the course by course develop awareness on water resources management. The average score of knowledge and awareness of the experimental group than the control group and when put to the test showed that there is a different level of statistical significance. 05 . The cause may be due to the activity of teaching experience to students in every unit. The unit 1 focuses for students to learn about the properties of water such as the water cycle. The water used each day with the students, however. Energy from water resources The second unit focuses on providing students 
with the knowledge of the amount of water resources available locally, planning water use, water quality monitoring of biological and physical quality of water. The units three are activities that enable students to review their own action against the resources of water each day, and the search to find ways to save water. The units four are activities that highlight the relationship between the lifestyles of the people of Thailand are very close to the water and create a culture that's pretty good. These results consisted with Laureano et al. (2008) studied the awareness of water resource management in the lake basin in the Mediterranean dimension of knowledge and ideas, coupled with the intent dimensional range is awareness. Their results showed that the group is showing awareness of water resource management through awareness level of students is manifested in a higher level because that person would be realized on any one thing. He must have been aware about the present state of things, what it is a preliminary and then climb down the importance of the issue and raise awareness in the system of values that can be changed or contribute to the development of the condition, the better. Our results consistent with the concept of Good (1973) which says that a key behavior to change behavior in a better way, and in line with the concept of Eiss (1975) that said that the learning of human caused recognition through the mental side first, then passed to the learning objectives in the cognitive skills and range, respectively. All activities in the curriculum suitable to develop awareness of water resource management and all activities are appropriate to the age, namely with regard to development tasks at different ages, with a focus on the learning of students, because of the tasks of human development at different ages to reflect the nature of development in each key aspect. In different ages of life, and take time to develop is appropriate, whether the ability of the cognitive skills group and the group are the elements that are inherent in the individual. The especially developmental tasks are mental side. Most people will have a view of the affective domain that most people think it is hard to develop; development work in this field is a challenge and the need to develop the same psychomotor domain and cognitive domain range. For this reason the developmental tasks at different ages, so the relevant and important to the development of human resources, especially in the current era of competition developmental tasks which has been studied since 1952 to the present. Has led the development of tasks, took part in the education of those involved or stakeholders of education to a study in Developmental Tasks. With the key principles intrude in all stages. The principle of curriculum development and teaching that achieve the goal of education consistent with the study of Sunchai (2003) was conducted using a set of teaching activities to raise awareness on the environment for grade 8 students in Yaha school Yaha district, Yala province which after the experiment, students are sure of increased environmental awareness. This is also consistent with the results of these five (Lao-hakote, 2008). Found that developing awareness of reforestation for the grade 7 students is required to develop a hierarchy of awareness. After the experiment, students made a higher hard drive. And is also consistent with the findings of static Sirithammachak (2009) found that creating awareness about environmental curriculum development at the ages of 12-15 years of activity in the practice-oriented curriculum.

The comparison of the knowledge and the awareness among the irrigated and non-irrigated before and after the intervention, mean scores were different, but the differences are not statistically significant level. 05 , and compare the average of the knowledge and the awareness among treatments in irrigated and non-irrigated posttest mean scores are different, but the differences are no statistically significant level. 05 . The cause may be due to this research is to develop awareness of water resources management for grade 6 students in Namphong sub-basin. This is an important development process is to create awareness to measure water resources management and the trial awareness of water resources management course. This work is published by a course of study, understanding and satisfaction of teachers on curriculum development, awareness on water resources management and efficiency programs develop awareness on water resources management. In the process of curriculum development has focused on the management of water resources is a key to ensuring that the course can be used to develop awareness on the management of water resources and irrigation in areas outside the irrigation district widely. Independent variables that used in this study is the district school was divided in irrigated areas and outside the irrigated area, by both the area to bring activities in the course of developing awareness of the resources deployed in the event teaching the same result. Before and after the course, the students had higher floors in the course of that activity has focused on the development of awareness to meet the aims of the course, the students have the comprehension the awareness of water resources management in the irrigate area and non-irrigate area scores were not significantly different. It might be because all life is related to water resources since birth, not only those in irrigated areas only, according to the study of studied the watershed study in the learning of science linking lifestyle Basin using five step process to develop a conscious awareness of life and wisdom. Five step processes taught science KWL has resulted in students an awareness of their local as possible. Students have the opportunity to learn. Experience the real local context. The lives of learning outside the classroom. Students were exposed to water resources Way of life is linked to the lessons. The students see the importance of local should learn to love and cherish. Yolao et al. (2000) have studied about the 
strength of the community to conserve water the case study of Sansaeb canal in Bangkok. It gives priority to people who are on community water sources. The Urban Community With the understanding aware of the damage that will occur with the water now and in the future. Motivation to help take care of public property is a water source that shows whether people will live in water or irrigated and non-irrigated, it is necessary to make people realize the importance of water resources as common property.

\section{Recommendations from the Research}

1) The development awareness of water resources management for students in primary school that is the learning process of affective domain as a whole to develop for long life education so supposed to pack into every level of basic education.

2) Office districts should clubs teacher who led the development of awareness programs on the management of water resources in Namphong sub-basin.

3) Office of Education should establish a budget support or encourage schools in the basin and outside the basin bring awareness to develop curriculum resources deployed in the curriculum to prepare students by training teachers. The understanding of the created by learning, activities, instrumentation and evaluation so that teachers in every class can organize learning about water resource management.

\section{Acknowledgements}

Thank you the Khon Kaen University for supporting us with a scholarship fund and The National Research University Project of Thailand, the Office of Higher Education Commission through the Cluster of Holistic Watershed Management for their support.

\section{References}

Bloom, B., Krathwhol, K., \& Masia, M. (1964). Taxonomy of educational objectives: The classification of educational goals. Handbook II: The affective domain. USA.: Allyn and Bacon, Boston.

Buarapa, W. (2004). An Application of GIS to the Mapping of the Sensitiveness for Groundwater Resource Contamination in Lower Nam Phong Watershed (Master of Science. Thesis in Remote Sensing and Geographic Information System, Graduate School, Khon Kaen University).

Cardaciotto, L. (2005). Assessing mindfulness: The development of a bi-dimensional measure of awareness and acceptance (Doctoral dissertation, Drexel University). Dissertation Abstracts International, 66(06), 3399 (UMI No. 3179140).

Clark, R. E., \& Squire, L. R. (1998). Human eyeblink classical conditioning: Effects of manipulating awareness of the stimulus contingencies. Psychol. Sci., 10, 14-18. http://dx.doi.org/10.1111/1467-9280.00099

Cohen, L., \& Manion, L. (1980). Research methods in education. London: Helm.

Department of Irrigation. (2006). The project plan includes the management of water resources in the basin species: Report Namhphong sub-basin. Bangkok: Ministry of Natural Resources and Environment.

Depraz, N. (1999). The phenomenological reduction as praxis. Journal of Consciousness Studies, 6, 95-110.

Depraz, N., Varela, F., \&Vermersch, P. (2003). On becoming aware: A pragmatics of experiencing. Philadelphia, PA: John Benjamins. http://dx.doi.org/10.1075/aicr.43

Eiss, A. F. (1975). Instructional Systems. Washington, D.C.: The National Science Teachers Association.

Freeman. (2000). How brains make up their minds. New York, NY: Columbia Press.

Good, C.V. (1973). Dictionary of Education. New York: McGraw-Hill Book.

Havighurst, R. J. (1952). Development tasks and education (2nd ed.). New York: McKay.

Karnden, \& Wannapok. (2006). Dictionary Thai-English. Bangkok: Matichon.

Krathwohl, D. R. (1985). Social and behavioral science research: A new framework for conceptualizing, implementing, and evaluation. San Francisco: Jossey-Bass.

Lao-hakote. (2008). Development of learning Activity thiough Service Learning for Enhancing Awareness of Forest-Resources Conservation among the First Year Secondary Students (Thesis in Development Strategy, Sakon Nakhon Rajabhat University).

Laureano P. et al. (2008). Conceptual frame on water culture and its use to raise public awareness on sustainable water management in the Mediterranean basin. Water culture and water conflict in the Mediterranean Area, $83,111-128$. 
Lavega, E. L. D. (2004). Awareness, Knowledge, and Attitude about Environmental Education: Responses from Environmental specialists, High school instructor, students, and parents (A dissertation for the degree of Doctor of Education in Curriculum and Instruction in the College of Education, University of Central Florida).

Ministry of Education. (2008). Core Curriculum 2008. Bangkok: Printing of Agricultural Cooperatives of Thailand.

Power, F. B. (2011). In the moment: A Phenomenological Case study of the dynamic nature of awareness and sensemaking (Dissertation submitted to the faculty of the graduate school of Education and Human Development, The George Washington University).

Royal Academy. (2002). Dictionary. Retrieve October 30, 2011, from http://rirs3.royin.go.th/coinages/webcoinage.php

Schiffries, C. M., \& Brewster, A. (2004). Water for a Sustainable and Secure Future: A Report of the Fourth National Conference on Science. Washington, D.C.: [n.p.].

Sirithammachak. (2009). The Effects of the 5E-Learning Cycle with Multiple Intelligences Approach and Teacher's Handbook Approach on Learning Achievement, Critical Thinking, and Awareness of Conservation of Environment of Mathayomsuksa 3 Students (Dissertation of Environmental Education, Mahasarakham University).

Sunchai, J. (2003). The development of awareness of the environment for grade 8 students at Ban Yaha school Yaha district Yala province (Thesis of Educational (Curriculum and instruction), Graduate school. Sukhothai Thammathirat University).

The Office of National Educational Commission. (2002). National Educational Act 1999 (The Revised Edition, the Second Issue ). Bangkok: Prigwan Graphic.

The Office of Secretariat in Educational Council. (2010). National Educational Plan, the Revised Issue (2009-2016) Concluded Issue. Bangkok: Prigwan Graphic.

UNESCO. (1997). International conference environment and society: Education and public Awareness for sustainability; Declaration of Thessaloniki. Retrieved October 2, 2006, from

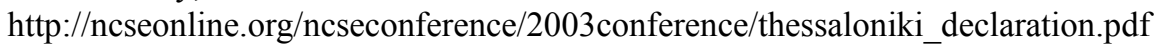

Varela et al. (1993). The Embodied mind. Cambridge, MA: MIT Press.

Yodmanee. (1989). Her Majesty Queen Sirikit on the environment. Bangkok: Office of National Identity. Prime Minister Secretariat.

Yolao, D. et al. (2000). Study Report Strengthening of communities to conserve water: Case Study Saen Saeb canal. Bangkok: Srinakharinwirot University.

\section{Copyrights}

Copyright for this article is retained by the author(s), with first publication rights granted to the journal.

This is an open-access article distributed under the terms and conditions of the Creative Commons Attribution license (http://creativecommons.org/licenses/by/3.0/). 